\title{
The effect of self-checkout quality on customer satisfaction and repatronage in a retail context
}

\author{
Teresa Fernandes ${ }^{1} \cdot$ Rui Pedroso ${ }^{1}$
}

Received: 12 July 2014/Accepted: 7 January 2016/Published online: 23 January 2016

(C) Springer-Verlag Berlin Heidelberg 2016

\begin{abstract}
Self-service technologies (SSTs) are defined as technological interfaces that enable customers to produce a service without direct employee involvement. Among various SSTs, self-checkouts are being tested by grocery stores across the world. However, while most studies focus on SST adoption, there is limited research on its impact on service quality, customer satisfaction, and retention. Our study investigates consumers' assessments of self-checkout in a retail outlet, and its influence on post-usage intentions. The study presents a causal model in order to determine (i) whether consumers evaluate service quality for self-checkout based on five different attributes: speed, ease-of-use, control, reliability, and enjoyment; (ii) whether the evaluation of service quality differs according to demographics and usage frequency; and finally (iii) if service quality delivered by self-checkout relates to overall customer satisfaction and retail patronage. We conclude that successful use of self-checkout may "tie" consumers to a provider, representing a feature that differentiates a retailer from competitors.
\end{abstract}

Keywords Self-service technologies · Self-checkout · Retail · Quality · Satisfaction · Repatronage

\section{Introduction}

Over the last decade, the way customers interact with firms has changed, mainly due to self-service technologies (SSTs), which have dramatically impacted the nature of service industries and the service delivery process (Wang et al. 2013; Orel and Kara 2014). The term self-service technology was first introduced by Dabholkar (1994) and refers to activities or benefits based on technology and carried out by the

Teresa Fernandes

tfernandes@fep.up.pt

1 Faculty of Economics, University of Porto, Rua Dr. Roberto Frias s/n, 4200-464 Porto, Portugal 
consumers themselves. Traditional interpersonal service encounters such as retail banking or airline check-in are gradually being replaced by SST interfaces (Wang et al. 2013). As more and more service companies adopt technologies to encourage consumers to perform services for themselves, it has become important to understand the potential impact of SST quality on customer satisfaction and purchasing intentions (Lee and Allaway 2002; Weijters et al. 2007; Oghazi et al. 2012; Collier and Kimes 2013; Lee et al. 2013). Previous research on SST adoption has found two categories of reasons driving customer usage: SST characteristics and individual difference variables (Elliott et al. 2013; Wang et al. 2013). Speed, control, reliability, ease-of-use, and enjoyment are viewed as important attributes in evaluating SST (Dabholkar 1996; Zhu et al. 2007). While results are not always consensual, adopters are generally young, well-educated males, with limited need for personal contact (Weijters et al. 2007; Lee et al. 2013). Other studies, e.g., Wang et al. (2012), also found that situational influences may impact SST usage.

However, since SST is a relatively recent service delivery method, a number of research gaps still exist (Beatson et al. 2007). In particular, reasons for its success from the customer's perspective are not yet clear (Marzocchi and Zammit 2006) and consumers' perceptions of service quality for SST have been overlooked (Lee et al. 2013). Moreover, among various SSTs, "off-site" options (such as online shopping or internet banking) have received relatively more attention in previous research than "on-site" options (Lin and Hsieh 2011; Orel and Kara 2014) ${ }^{1}$. In the particular case of self-checkout in retail stores, little is known due to its recent introduction and specific literature (e.g., Anselmsson 2001; Dabholkar et al. 2003, Weijters et al. 2007; Wang et al. 2012) is difficult to find (Marzocchi and Zammit 2006; Lee et al. 2013; Wang et al. 2013). Therefore, there is a notable need for both researchers and practitioners to examine customer expectations of SST service quality in the emerging customer-technology interaction-based service settings (Lin and Hsieh 2011). Also, while most studies focus mainly on reasons for adoption and intention to use SSTs, there is little research on post-usage behavior, namely SST impact on customer satisfaction and retention (Beatson et al. 2007; Lee et al. 2009; Wang 2012; Orel and Kara 2014).

Our study contributes to bridging these literature gaps, focusing not only on understanding SST adoption, namely in the understudied field of self-checkout in retail stores, but also on customer evaluation of the service quality of SST and its impact on customer satisfaction and retail patronage. The main research issues of our study are to understand how customers' post-usage intentions in a retail outlet are influenced by their perceptions of service quality with self-checkout, what evaluation criteria they use, and if this evaluation is influenced by customer traits. Scant research has been conducted on service quality of SSTs in general (Lin and Hsieh 2011) and self-checkout in particular (Lee et al. 2009). However, with the increasingly widespread use of this technology, quality may be a more critical issue than adoption. Since the best fit to measure self-checkout quality remains to be found, the discussion continues about whether researchers should focus on developing specific scales for different settings, or on testing existing models in

\footnotetext{
${ }^{1}$ See Wang et al. (2013) for a chronological review of major empirical SST studies.
} 
various contexts. In this study, we will test an existing model of key drivers of service quality on the specific context of self-checkout. We adopt Dabholkar's (1996) attribute-based model in order to examine whether consumers evaluate service quality for self-service checkouts based on the five attributes considered: speed, ease-of-use, control, reliability, and enjoyment. Second, this study investigates if the evaluation process of service quality differs by customer demographics and usage frequency. In the context of SST, previous research tends to be focused on examining individual differences in off-site rather than on-site options (Lee et al. 2013) and has produced varying results (Kelly et al. 2010). Also, its influence hasn't yet been fully covered by the existing literature on self-checkout adoption (Weijters et al. 2007). Thus, our understanding of these differences in the service evaluation process while using self-checkouts is still very limited. Finally, we examine the impact of customer's assessment of self-checkout quality on commonly included outcome constructs in service decision-making, namely overall satisfaction and retail patronage. Previous studies were mainly focused on SST adoption, but little is known about how service quality delivered by SST relates to post-usage intentions (Orel and Kara 2014). Since customers tend to evaluate a service provider in terms of their total service offerings (Reinders et al. 2008), we expect that the evaluation process of SST quality will have a positive effect on overall satisfaction of the experience, which in turn will not only have a positive impact on the intention to reuse SST, but also on the intention to patronize the store in the future (Marzocchi and Zammit 2006). The empirical context of the study is a real-life retail scenario, namely a store in a large Portuguese supermarket chain, with randomly chosen respondents filling out the questionnaire on-site during self-checkout.

The remainder of this paper is organized as follows. The next two sections focus on the relevant literature and on the development of the hypotheses. The investigation undertaken to test the conceptual framework is then described. Following a description of the methodology, the results are presented. A discussion of the research findings, managerial implications, and future research directions conclude the paper.

\section{Self-service technologies and self-checkout}

The sizeable shift from products to services in the GDP of many economies, along with the increasing use and importance of the Internet and other technological advances are significantly impacting marketing strategies and enhancing the scale and scope of customers' self-production (Oghazi et al. 2012) and the concept of SST has gained widespread interest in recent years (Elliott et al. 2013). SSTs are defined as technological interfaces that enable customers to produce a service that is free from direct service employee involvement (Meuter et al. 2005; Zhu et al. 2013). SSTs lead to active customer participation in the co-production of service (Vargo and Lusch 2008; Hilton and Hughes 2013), which is a component of value cocreation (Lusch and Vargo 2006). This participation is critical for providers, with consumers making an important contribution to service productivity. According to 'Service-Dominant Logic', customers are vital 'operant' resources, co-creators of 
value, and potentially a major source of competitive advantage (Lusch and Vargo 2006).

A combination of computer, telecommunications, and internet technology is now being widely used for a variety of service delivery purposes, namely in the retail environment (Walker and Johnson 2006). The last decades have seen advances in technology that are able to respond both to consumers' preferences and retailers' needs (Zhu et al. 2013; Renko and Druzijanic 2014), such as touch screen displays, smart mirrors, mobile applications, automatic payment modalities, or radio frequency identification (Kallweit et al. 2014; Pantano and Viassone 2014). The increasing use of SST by retailers has created a growing need for classifying different types of SST (Elliott et al. 2013), with several SST taxonomies being proposed in the literature (e.g., Meuter et al. 2000; Cunningham et al. 2008). According to Dabholkhar and Bagozzi (2002) and Lee et al. (2013), the wide range of SST available can be generally divided into two types: "off-site" options, such as telephone and online banking and internet shopping; and "on-site" options, such as automatic teller machines (ATMs), pay-at-the-pump gas station terminals, automated airline ticketing, hotel checkout, in-store kiosks, and the main subject of this study-supermarket self-checkout systems (Weijters et al. 2007; Yang and Klassen 2008; Orel and Kara 2014). Whereas off-site technologies have already been intensively researched, understanding customers' assessments of on-site technologies in retail remains a challenge for researchers (Wang 2012; Lee et al. 2013; Wang et al. 2013). A broad overview of the relevant literature on retail self-checkout is provided in Table 1.

Table 1 Overview of the relevant literature on self-checkout in retail settings

\begin{tabular}{|c|c|c|c|}
\hline Study & Theory/model & Factors considered & Findings \\
\hline $\begin{array}{l}\text { Dabholkar } \\
\text { et al. (2003) }\end{array}$ & Dablokhar & $\begin{array}{l}\text { Speed, ease-of-use, reliability, } \\
\text { enjoyment, and control, attitudes, } \\
\text { personal interaction }\end{array}$ & $\begin{array}{l}\text { The factors considered } \\
\text { drive SST usage/ } \\
\text { avoidance }\end{array}$ \\
\hline $\begin{array}{l}\text { Marzocchi } \\
\text { and Zammit } \\
(2006)\end{array}$ & & $\begin{array}{l}\text { Hedonism, control, personnel } \\
\text { responsiveness, information }\end{array}$ & $\begin{array}{l}\text { The factors considered } \\
\text { drive satisfaction and } \\
\text { repurchase }\end{array}$ \\
\hline $\begin{array}{l}\text { Weijters et al. } \\
\text { (2007) }\end{array}$ & TAM & $\begin{array}{l}\text { Usefulness, ease-of-use, reliability and } \\
\text { fun, customer demographics }\end{array}$ & $\begin{array}{l}\text { The factors considered } \\
\text { drive SST attitude and } \\
\text { usage }\end{array}$ \\
\hline $\begin{array}{l}\text { Elliott et al. } \\
\text { (2012) }\end{array}$ & TAM, TRI & $\begin{array}{l}\text { Usefulness, ease-of-use, reliability and } \\
\text { fun, technology readiness }\end{array}$ & $\begin{array}{l}\text { Factors drive SST attitude, } \\
\text { TR impacts reliability } \\
\text { and fun }\end{array}$ \\
\hline $\begin{array}{l}\text { Wang et al. } \\
\text { (2012) }\end{array}$ & & $\begin{array}{l}\text { Usefulness, ease-of use, risk, control, } \\
\text { fun, individual traits, situational } \\
\text { factors }\end{array}$ & $\begin{array}{l}\text { Factors drive attitudes } \\
\text { towards SST and } \\
\text { adoption }\end{array}$ \\
\hline $\begin{array}{l}\text { Lee et al. } \\
\quad(2010,2013)\end{array}$ & $\begin{array}{l}\text { Dablokhar, } \\
\text { TAM }\end{array}$ & Demographic factors, consumer traits & $\begin{array}{l}\text { Consumer traits drive SST } \\
\text { usage }\end{array}$ \\
\hline $\begin{array}{l}\text { Orel and Kara } \\
\text { (2014) }\end{array}$ & SSTQUAL & $\begin{array}{l}\text { Functionality, enjoyment, security, } \\
\text { design, assurance, convenience, } \\
\text { customization }\end{array}$ & $\begin{array}{l}\text { Five factors impact quality, } \\
\text { satisfaction, and loyalty }\end{array}$ \\
\hline
\end{tabular}


The idea of having customers take on a partial employee role during a transaction has wide appeal and is highly advantageous for service providers (Curran and Meuter 2005). Increasingly, supermarkets are viewing self-checkout as an alternative to hiring and training staff, and thus as a source of potential savings (Walker et al. 2002; Dabholkar et al. 2003; Orel and Kara 2014), increased productivity (Curran et al. 2003; Weijters et al. 2007; Wang 2012), and a way to reach new customer segments (Bitner et al. 2002; Elliott et al. 2012). The use of SST also limits problems usually associated with heterogeneity and perishability by providing a more consistent service atmosphere, since the human element of service delivery is eliminated or minimized (Hsieh et al. 2004; Beatson et al. 2007; Elliott et al. 2013). Furthermore, it allows service providers to reclaim valuable floor space for additional sales (Collier and Kimes 2013) and to redeploy their employees to areas where special customer service is needed (Lee and Allaway 2002; Lee et al. 2013). However, it is less clear why customers would prefer to consume selfservices (Walker and Johnson 2006; Oghazi et al. 2012). Since provider-client interaction is an essential feature of service delivery, implementing technologybased self-service can be challenging (Wang et al. 2012; Hilton et al. 2013). Customers are invited to play an active role in service co-creation through selfservice, but this may only be achieved if consumers are willing to participate (Rodie and Kleine 2000; Anitsal and Schumann 2007). Customers must be convinced of the value of SST before foregoing a full service alternative, and they are not naturally inclined to change channel options unless motivated to do so (Collier and Kimes 2013). In fact, some studies suggest that while some consumers actively seek SST, others intentionally avoid them (Elliott et al. 2012), and many customers still consider self-services unattractive (Oghazi et al. 2012). Hence, the willingness to co-produce is influenced by the benefits a customer may expect to receive. Without perceived benefits, customers will refuse to use the SST or postpone using it until no other alternative is available (Liljander et al. 2006). Given the fixed cost of establishing these technologies, this could ultimately lead to a lack of return on investment, a significant drain on resources, and frustration on the part of providers (Collier and Kimes 2013; Lee et al. 2013; Renko and Druzijanic 2014), thus turning SST into a "double-edged sword" (Lee and Allaway 2002). This is particularly true with technology that is intended for use by the customer (Curran and Meuter 2005), and therefore knowing how consumers evaluate the quality delivered by technology-based services is a critical issue to be considered (Riel et al. 2011; Lee et al. 2013; Kallweit et al. 2014).

\section{Antecedents and outcomes of SST adoption and evaluation}

The evaluation of SST used by grocery stores is becoming increasingly important as retailers expand their offers and more and more customers utilize such services (Orel and Kara 2014). Although research on SST, particularly on self-checkout is relatively new, some important work has been done on this topic. Studies on SST have been conducted in a broad range of research contexts, using many different research designs and examining a great variety of different technologies (Kallweit 
et al. 2014). This research has produced several SST adoption factors related to SST characteristics, individual differences, and situational influences (Wang et al. 2012; Elliott et al. 2013; Lee et al. 2013; Wang et al. 2013). However, according to Kelly et al. (2010), there is no evidence of a widely accepted SST adoption model.

Early literature mainly used the TAM (Davis 1989) or related models such as the TRA as a theoretical basis (Kallweit et al. 2014). First introduced in literature on information technology systems, the technology acceptance model (TAM) has been frequently used to examine variables that influence consumers' usage intentions of technological products or services. Based on the theory of reasoned action (TRA) from Ajzen and Fishbein (1980), the TAM suggests that beliefs about technology, namely perceived usefulness and perceived ease-of-use, influence attitudes, which in turn lead to intentions and, ultimately, usage. The TAM has been extended and tested with different variables in various applications. To provide a broader view and better prediction of users' technology acceptance, perceived enjoyment was incorporated into the TAM since adoption may be determined by both extrinsic and intrinsic motivations (Davis and Wiedenbeck 2001). Though adaptable to different contexts, findings show that the TAM could not fully explain SST adoption (e.g., Curran and Meuter 2005), especially when SSTs are deeply influenced by social context and co-creation of value (Baron et al. 2006). The TAM mainly explains the adoption of service technology, while SST also implies the adoption of the selfservice concept (Kelly et al. 2010). Dabholkar and Bagozzi (2002) have suggested that the perceived usefulness dimension is not relevant for technology-based selfservices in which the consumer participates but does not own.

More recent literature has strengthened previous studies and developed the framework of consumers' adoption of SST. An important addition influencing adoption research was made by Parasuraman (2000), who developed the Technology Readiness (TR) index as a framework identifying four dimensions of individuals' attitudes towards technology, with optimism and innovativeness as contributors to TR, and discomfort and insecurity as inhibitors. Extant research (e.g., Lin and Hsieh 2007; Zhu et al. 2007; Elliott et al. 2012) focuses on the relevance of TR to SST adoption. However, other studies (e.g., Liljander et al. 2006; Chiu et al. 2010) challenge the importance of TR in explaining SST adoption behavior. Namely, the TR of adopters and non-adopters of SST was not found to differ significantly and it was suggested that TR measurements may need to be adapted to specific contexts (Kelly et al. 2010). Other consumer traits (e.g., the need for personal contact) and technology attributes were found to be stronger predictors of SST adoption, either as direct antecedents or moderators.

Dabholkar (1996) was among the first to investigate the service quality of SST, specifically with on-site options, presenting two alternative models: an attributebased model and an overall affect model. The attribute-based model suggests that consumers evaluate service quality using a compensatory process where attributes related to the SST are combined. The overall affect model suggests that evaluations of service quality are driven by two predispositions, including attitude towards using technological products and the need for interaction with a service employee. The attribute-based model suggests that five attributes are important determinants of expected service quality of SST. In addition to Dabholkar's (1996) models, a 
number of other studies have identified key drivers of SST evaluation (e.g., Meuter et al. 2000; Curran and Meuter 2007; Lin and Hsieh 2011), including self-checkout (Table 1). The complexity of these factors precluded the inclusion of all of them in this study, although they are all relevant to the topic of SST service quality. Among them, Dabholkar's five attributes, namely speed of delivery, ease-of-use, reliability, enjoyment, and control, remain the most important attributes in evaluating SST cited in the literature (Orel and Kara 2014).

\subsection{Speed of service delivery}

The most obvious advantage offered by self-checkout is that it reduces the amount of time spent at the checkout (Marzocchi and Zammit 2006). Speed of transaction is defined as the time it takes to actively complete a transaction via a SST (Dabholkar 1996) and has been mentioned since the earliest studies on SST (e.g., Langeard et al. 1981; Bateson 1985) as an important consideration for customers (Collier and Kimes 2013). SST can be assumed to be an alternative channel for consumers who want to reduce service delivery time (Lee et al. 2013). SST can be used to overcome the perceived time and location constraints of a full service offering and can be the deciding factor on which service channel to use (Collier and Sherrell 2010). Customers who commonly strive to make the most efficient use of their time may prefer not to interact with employees in a full service encounter (Rodie and Kleine 2000; Durkin, 2004). The speed of service delivery provided by this technology results in time savings (Ding et al. 2007) and reduced waiting time for consumers (Walker et al. 2002; Beatson et al. 2007). SST studies mention speed of transaction as one of the most influential factors leading to customer satisfaction (e.g., Meuter et al. 2000; Howard and Worboys 2003; Collier and Kimes 2013). The longer consumers have to wait for a service, the less satisfied they will be with the service itself. Conversely, if customers expect that a service will be delivered speedily, they are likely to evaluate the service more highly (Dabholkar 1996) which may affect their overall satisfaction (Collier and Sherrell 2010).

\subsection{Perceived control}

Perceived control can be viewed as the amount of control that a customer feels he/ she has over the process/outcome of a service encounter (Bateson and Hui 1987). From a self-service perspective, perceived control is defined as a belief in one's ability to command and exert power over the process and outcome of a self-service encounter (Collier and Sherrell 2010). Some customers tend to feel more in control when they perform the service for themselves (Bateson 2000; Rodie and Kleine 2000; Dabholkar et al. 2003). Consumers mainly use self-service to feel in control, not for monetary savings (Bateson 1985). One of the primary advantages for customers' taking on a co-production role in a service experience is the idea of control-namely, control of the pace of the transaction, the level of desired interactivity, the handling and packaging, and ultimately the output of the servicethus perceiving spatial and temporal freedom and autonomy (Lin and Hsieh 2007; Wang 2012). Beyond individual abilities and a sense of self-confidence (Walker and 
Johnson 2006), control perceptions also depend on external conditions, such as e.g., accessibility of the technology, perceived crowding, and other situational factors (Collier and Sherrell 2010; Wang 2012). According to Bateson (1985) and Anselmsson (2001), the higher the level of perceived control by consumers while experiencing a service, the higher their degree of satisfaction. According to Meuter et al. (2000), control perceptions influence satisfaction from using technology, while also lowering risk perceptions and increasing adoption intention (Lee and Allaway 2002; Elliott et al. 2012). Dabholkar (1996) showed that perceived control had a positive impact on the intention to use SST and on service quality evaluation. Marzocchi and Zammit (2006) further confirm that the consumer's sense of control associated with the use of self-scanning has a positive impact on self-service satisfaction. Conversely, a diminished sense of control may reduce customer satisfaction (Bateson and Hui 1987). According to Collier and Sherrell (2010), lack of control can frustrate customers and discourage future further self-service transactions. In fact, perceived control was identified as one of the discriminating factors between users and non-users of SST (Walker et al. 2002; Howard and Worboys 2003).

\subsection{Reliability}

Reliability is an important dimension of service quality (Parasuraman et al. 1988), including technology-based services (Davis 1989). Reliability involves consistency of performance and dependability, or the ability to perform the promised service dependably and accurately (Parasuraman et al. 1988), thus reducing perceived risk (Curran and Meuter 2005). Weijters et al. (2007) refer to reliability as the extent to which the SST consistently and accurately performs the expected task. Reliability thus refers to the correct technical functioning of an SST and the accuracy of service delivery (Walker and Johnson 2006). Evans and Brown (1988) suggest that reliability plays a critical role in customer technology acceptance and Davis (1989) found dependability to be an important dimension in the use of computer technology. According to Zhu et al. (2013), the risks of malfunctioning SSTs include dissatisfaction and loss of sales. Also Ding et al. (2011) found a relationship between self-service accuracy and customer satisfaction, while Dabholkar (1996) found that reliability and accuracy are relevant for evaluating technology-based self-service options.

\subsection{Ease-of-use}

Ease-of-use has been defined as the degree to which a person believes that using a particular system is free of effort (Davis 1989). Ease-of-use thus relates to the efforts a customer needs to make in order to effectively use the new service process and enjoy its expected advantage (Timmor and Rymon 2008). SST effort perceptions may be influenced by e.g., the physical location, operating hours, and overall availability of the SST. These situational factors can determine the perceived ease-of-use (Collier and Sherrell 2010). Customers may associate ease-of-use with less effort spent, on the one hand, and reduced social risk, on the other (Dabholkar 1996). A customer who tends to avoid self-service may feel anxious over expected extra efforts in terms of physical and mental exertion, since people in general are not 
equipped with the necessary skills and confidence (Lee et al. 2013). Also, if customers perceive self-service to be difficult to use, they may feel uneasy about looking foolish while using it (Oghazi et al. 2012). Ease-of-use reflects the extent to which customers expect SST to be easy to learn and use, and is positively linked to customers' willingness to reuse SST (Davis and Wiedenbeck 2001). Ease-of-use is a critical factor in explaining consumer perceptions and behaviors regarding SSTs (Zhao et al. 2008). Studies in several domains-e.g., online shopping, online banking, health services-have shown positive relationships between ease-of-use, adoption of and satisfaction with a new service (DeJong et al. 2003; Lim and Dubinsky 2004; Curran and Meuter 2005).

\subsection{Enjoyment}

Hirschman and Holbrook (1982) first defined hedonic consumption as reflecting the potential entertainment associated with a shopping experience, besides more utilitarian motivations. The use of SSTs may be considered as a source of fun by consumers who derive pleasure from interacting with machines (Childers et al. 2001), reflecting the hedonistic aspect of using SST (Weijters et al. 2007). Novelty (Rodie and Kleine 2000; Hilton and Hughes 2013) or the mere fascination with SST capabilities (Meuter et al. 2000) may also motivate customers to participate. Although from a utilitarian perspective customers are mainly concerned with performing their task in an efficient and timely manner, they may still enjoy the process of performing the activity itself (Oghazi et al. 2012). Customers who enjoy playing with machines are likely to use self-service options just for fun (Dabholkar 1996). Enjoyment refers to the extent to which the activity of using technology is perceived to provide reinforcement in its own right, apart from any performance consequences that may be anticipated (Davis 1989). Thus, SST usage is not only triggered by extrinsic motives relating to efficiency, but also by intrinsic motives relating to the enjoyment of using modern technologies (Childers et al. 2001; Wang 2012). Curran and Meuter (2007) and Davis (1989) concluded that enjoyment influences the use of technological devices. Also Dabholkar (1996), Dabholkar and Bagozzi (2002) and Anselmsson (2001) consider that enjoyment with the use of SST systems is one of the main attributes determining evaluations of service quality.

Understanding the underlying motives that trigger positive evaluations and satisfaction with SSTs has important implications for customer-firm relationships (Meuter et al. 2000). As SSTs increasingly replace service employees, customers are increasingly performing the service task or producing the service by themselves (Hilton and Hughes 2013). Though this participation is critical for providers, the loss of the social bond element and of the interpersonal aspect of service encounters may have an impact on consumer satisfaction and retention (Beatson et al. 2007). Some consumers view the service encounter as a social experience, value interpersonal interactions, and prefer to deal with people (Curran and Meuter 2005). In fact, recent studies (e.g., Dabholkar et al. 2003; Meuter et al. 2003; Walker and Johnson 2006) have listed the customer's need for human interaction as one of the main reasons for not adopting SST (Collier and Kimes 2013). Some consumers may also see the 
introduction of SST as a threat, may be unsure of how problems in dealing with the technology are solved, and may continue to do things as they have always done (Curran and Meuter 2005). Also, customers are expected to perform an increasing number of services themselves, and getting them to allocate resources to completing a task and feeling satisfied is a challenge (Liljander et al. 2006; Collier and Kimes 2013). Thus, it is important to understand not only the motives that drive consumers to use SSTs in general, and supermarket self-service checkouts in particular, but also their potential impact on consumers' assessments associated with the post-usage of SSTs and their experience with a company, such as service quality, customer satisfaction, and future intentions (Beatson et al. 2006; Wang 2012). It is well established that customer satisfaction can affect customer retention (Meuter et al. 2000) and that satisfaction in a self-service experience is a determinant for future use (Ding et al. 2011). If the use of self-service checkouts generates customer satisfaction-i.e., if consumers are pleased with the performance of SSTs based on attributes they consider important - this may have an impact on consumers' intention to patronize the store (Weijters et al. 2007), thus representing a feature differentiating a retailer from its competitors (Marzocchi and Zammit 2006; Lee et al. 2013). However, little is known about how service quality delivered by self-checkout relates to customers' overall satisfaction and retail patronage (Lee et al. 2009).

\section{Research framework and methodology}

Our research focuses on the self-checkout attributes as drivers of customer service evaluation. Three commonly included outcome constructs in service decisionmaking were incorporated in the model: quality, satisfaction, and repatronage. We also consider that frequency of use and consumers' characteristics influence the

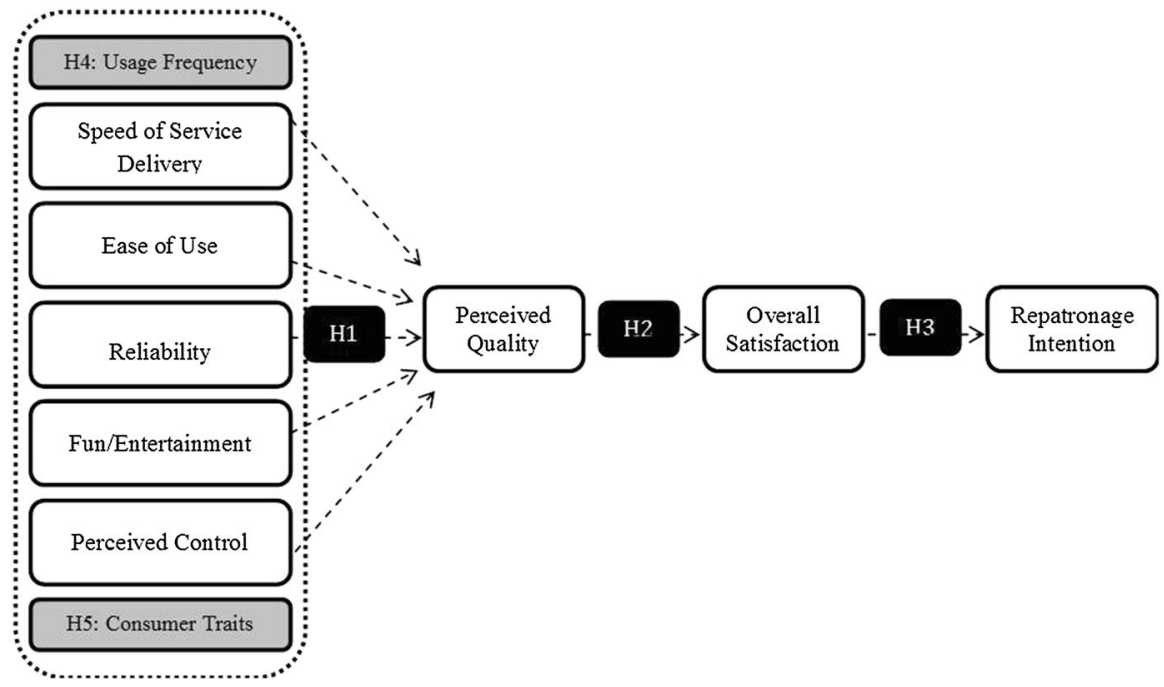

Fig. 1 Research model 
evaluation of self-checkout attributes. According to the literature review, we propose the following research framework and hypothesis (Fig. 1):

We go on to test the following hypothesis:

Hypothesis 1 (H1) Self-checkout attributes [speed, ease-of-use, reliability, enjoyment, and control] will have a positive effect on the service-perceived quality.

We adopt Dabholkar's (1996) attribute-based model in order to examine whether consumers evaluate service quality for self-service checkouts considering five attributes: speed, ease-of-use, control, reliability, and enjoyment. The main idea of Dabholkar's attribute-based model is that consumers evaluate service quality using a compensatory process where attributes related to the SST are combined. Parasuraman et al. (1988) describe service quality as an overall evaluation, similar to an attitude (Elliott et al. 2012). However, following e.g., Kallweit et al. (2014) and Orel and Kara (2014), we adopt a narrower focus of service quality considering the unique nature of SST. The positive evaluation of using SSTs is a prerequisite for a favorable perception of service quality (Kallweit et al. 2014).

Researchers link service quality to consumer behavior either directly or indirectly via customer satisfaction (Lee et al. 2009), suggesting that perceptions of service quality drive satisfaction, which in turn drives behavior. Most researchers seem to agree that the two constructs (service quality and customer satisfaction) are distinct, although related. While the process of forming perceptions of service quality is mainly cognitive, customer satisfaction judgements are influenced both by cognitive and affective elements, as they are evaluation- and emotion-based responses (Oliver 1997). Satisfaction is defined as the degree to which an individual derives positive feelings from consumption (Lin and Hsieh 2006), or as a judgement by the consumer that the product or service provides a pleasurable level of consumption-related fulfillment (Lin and Hsieh 2007). Also Oliver (1997) argues that satisfaction is a customer "fulfilment response", a post-purchase phenomenon that portrays how much the customer likes or dislikes the service. In the context of technology-based self-services, recent studies have shown the relevance of perceived service quality for customer satisfaction (Kuo et al. 2009; Dabholkar and Spaid 2012; Orel and Kara 2014) and retail patronage (Lee et al. 2009; Lee and Yang 2013). The importance of self-service evaluation has been identified in the literature, namely its impact on overall satisfaction: if a consumer is satisfied with an SST based on attributes they consider important, they are likely to be satisfied with the overall experience (Meuter et al. 2000). Also, according to Collin and Sherrell (2010), previous research has noted that, as customers experience more benefits in a service, their satisfaction increases. Thus we propose that:

Hypothesis 2 (H2) Self-checkout perceived quality will have a positive effect on customer overall satisfaction.

Likewise, if a consumer has a satisfying overall experience with the organization, it is likely that he/she will want to return to the organization in the future (Beatson et al. 2007). Therefore, supermarkets assume that SST will enhance the customer experience and ultimately retail patronage (Orel and Kara 2014). Evidence for the significant positive impact of customer satisfaction on behavioral intentions comes from a variety of service research (Lin and Hsieh 2007), both in traditional and 
technological contexts (Orel and Kara 2014). Prior research identified satisfaction as a primary driver of product repurchases (Wang et al. 2013). In the context of SST usage, a customer who is satisfied with the quality of the services received is believed to be less likely to switch to alternatives and will attempt to develop a closer relationship with his or her current service provider (Wang 2012). In their study on the forced use of SST, Reinders et al. (2008) found that attitudes towards SST usage had an impact on attitudes towards the service provider, namely switching intentions. Thus, we expect overall satisfaction of the experience to have a positive impact on the intention to repatronize the store in the future (Marzocchi and Zammit 2006):

Hypothesis 3 (H3) Overall customer satisfaction will have a positive effect on repatronage intention.

We also posit that frequency of use and consumer characteristics will influence self-checkout attribute evaluation. Usage frequency should be relevant, because the more consumers interact with SSTs, the more skilled and less anxious they become with their role (Beatson et al. 2007; Wang et al. 2013). Since frequent users are also more experienced and knowledgeable, they will feel fewer barriers to adopting SST (Rodie and Kleine 2000; Hilton et al. 2013). Customers who usually use selfscanning checkouts are likely to consider all of the above attributes important and familiarity with SST systems affects their satisfaction levels (Meuter et al. 2003). According to Buell et al. (2010), channel enthusiasts, who chose to concentrate their transactions through specific self-service channels, may be more likely to become efficient and feel confident and in control of the service, and thus might experience higher satisfaction. Compared with those that do not use it regularly, these consumers will perceive self-scanning as offering greater control, as well as being faster, more reliable, easy to use, and entertaining (Dabholkar et al. 2003).

Also, age (e.g., Ding et al. 2007; Simon and Usunier 2007; Dean 2008), gender (e.g., Elliott and Hall 2005; Lee et al. 2013), and education (e.g., Meuter et al. 2005; Weijters et al. 2007) have been considered as important determinants of acceptance (Meuter et al. 2003). Customer demographics and its influence on shopping behavior have been of interest to researchers for decades, but the concept has not yet been fully explored in the existing literature on technology adoption (Weijters et al. 2007), which has produced varying results (Lee et al. 2010). The varying results of the SST research into demographics may be explained to some extent by the cross-cultural differences or the changing influence of different demographic features over time based on changes in society (Kelly et al. 2010). Some authors have concluded that demographics start to matter less with the wider dissemination of technology in one's everyday social and business life (Nilsson 2007), while other studies confirm that differences exist. For instance, past research found that younger and better educated males were more likely to appreciate SST (Langeard et al. 1981; Dabholkar et al. 2003; Rayport and Jaworski 2004). Older people, who tend to be less familiar with and have less access to new technologies in general, were more reluctant to use it (Howard and Worboys 2003) because of the challenges they face in understanding and using these devices (Im et al. 2003). Age is also considered an antecedent to the preference for personal contact (Lee et al. 2010) and increasing age was found to have a negative effect on user confidence and belief in the benefits of SST (Dean 2008). In 
terms of gender, Lee et al. (2013) empirically prove the differential effects of ease-ofuse of self-service kiosks across gender, since females generally experience higher anxiety than males in using technologies. According to Weitjers et al. (2007), males attach more importance to making their shopping more efficient using SST and are more likely to focus on the benefits of using the technology than women are. Furthermore, e.g., Elliott and Hall (2005) showed that females tend to feel a lack of control and confidence over technology in operating SSTs, and they are more strongly influenced by perceptions of ease-of-use. In terms of education, results by Weitjers et al. (2007) show that more highly educated customers are likely to appreciate the innovativeness of the technology, whereas less educated customers might rather avoid the novelty of such technologies. Thus, we posit that:

Hypothesis 4 (H4) Frequency of use will influence self-scanning checkout attribute evaluations.

Hypothesis 5 (H5) Consumer characteristics, namely age, gender, and education, will influence self-scanning checkout attribute evaluations.

A large Portuguese supermarket chain offering self-checkout was chosen for this study. Supermarket self-checkout machines have only recently been introduced in some selected supermarkets and this offline retailing context has rarely been examined in the literature, providing an additional research benefit to this setting (Wang et al. 2012). Self-checkouts were introduced as an alternative to traditional checkouts, with customers having the option of choosing either (Wang et al. 2013). Data were collected through a self-administered cross-sectional survey. Each question was based on the existing literature and, with the exception of the initial questions regarding consumer characteristics and frequencies of use, respondents were asked to express their opinion using a seven-point Likert scale. Data collection was similar to a mall-intercept method, with randomly chosen respondents filling out the questionnaire on-site during self-checkout, resulting in 294 usable responses.

The questionnaire comprised 20 questions and was divided into four sections, including (i) attributes related to self-checkout usage (assessed through a two-item measure for each attribute, adapted from Dabholkar 1996 and Dabholkar et al. 2003) as well as (ii) consumer characteristics and (iii) frequency of use. Respondents were also asked about (iv) their level of overall satisfaction (defined as an evaluation based on the consumer's overall experience with the supermarket and assessed through a single-item measure) and intention to repatronize (defined as whether the availability of self-checkout will increase store patronage and assessed through a single-item measure). A causal model was developed in order to determine the relationship between service attributes, satisfaction, and repatronage.

\section{Findings}

The majority of the respondents were female (54.1\%), with an average age of approximately 40 years old, and had finished high school $(33.3 \%)$ or had a bachelor's degree $(32.6 \%)$. In terms of age, we can observe from Table 2 that the 
Table 2 Descriptive statistics for respondents' age

\begin{tabular}{lclll}
\hline Age & Frequency & Percent & Valid percent & Cumulative percent \\
\hline$<23$ years & 50 & 17 & 17,1 & 17,1 \\
$24-30$ & 39 & 13,3 & 13,4 & 30,5 \\
$31-35$ & 39 & 13,3 & 13,4 & 43,8 \\
$36-40$ & 46 & 15,6 & 15,8 & 59,6 \\
$41-50$ & 38 & 12,9 & 13,0 & 72,6 \\
$51-55$ & 39 & 13,3 & 13,4 & 86,0 \\
$\geq 55$ & 41 & 13,9 & 14,0 & 100 \\
Missing & 2 & 0,7 & 100 & \\
Total & 294 & 100 & & \\
\hline
\end{tabular}

different percentages are very close to each other, showing that the use of selfcheckout is a somewhat transversal phenomenon.

The frequency of usage of self-checkout systems shows that $38.4 \%$ of those surveyed use this technology frequently, 34.7\% always do use it, $20.4 \%$ occasionally do so, and $6.5 \%$ rarely use it. Thus, overall more than $70 \%$ of respondents use self-checkout regularly.

Exploratory factor analysis (EFA) and reliability tests were performed on the items used to measure self-checkout attributes. Regression analysis was performed between self-checkout attributes and perceived quality, between perceived quality and overall satisfaction, and between overall satisfaction and repatronage.

We conducted an EFA via the method of principal component analysis, using varimax rotation for self-checkout attributes. A value of Kaiser-Meyer-Olkin (KMO) equal to 0.816 , and Bartlett's test with a $p$ value $<0.001$ indicated that there was a significant correlation between the variables and the data are appropriate for a factor analysis. The results strongly support the five-factor structure (Table 3), with a total explained variance of $85.9 \%$.

The scales demonstrated good reliability according to accepted standards (Nunnally 1978). Internal reliability tests of the identified factors showed strong Cronbach's alpha (ranging from .75 to .89) and average variances extracted (ranging from 63.7 to $79 \%$ ). In addition, evidence of the validity of the measures is provided by the fact that all factor loadings are significant and that the scales exhibit high levels of internal consistency (Fornell and Larcker 1981). The scales are reported in Table 3 along with reliability, validity, and dimensionality statistics.

Hypothesis 1 aims to determine to what extent perceived quality of self-checkout (dependent variable) is explained by its attributes, namely speed, ease-of-use, reliability, enjoyment, and control (independent variables). We thereby proceeded to multiple linear regression analysis, a statistical technique used to analyze the relationship between a single dependent variable and several independent variables (Hair et al. 2009).

Multiple regression analysis showed all factors (attributes) to be significant. Speed of using the service, ease-of-use, and reliability emerged as important determinants of customers' evaluation of self-checkout quality. Perceived control 
Table 3 Measurement scales, reliability, validity, and dimensionality statistics for self-checkout attributes

\begin{tabular}{|c|c|c|}
\hline Measures & PCA loadings & $\alpha(\mathrm{AVE})$ \\
\hline Speed & Mean 5.732 & $.85(.680)$ \\
\hline The self-scan saves me time & .849 & \\
\hline The self-scan lets me checkout quickly & .800 & \\
\hline Ease-of-use & Mean 6.109 & $.75(.637)$ \\
\hline The self-scan is easy to use & .872 & \\
\hline The self-scan does not take much effort & .716 & \\
\hline Reliability & Mean 5.933 & $.76(.697)$ \\
\hline The self-scan is accurate & .865 & \\
\hline The self-scan is reliable & .804 & \\
\hline Entertainment & Mean 5.677 & $.89(.703)$ \\
\hline I enjoy using the self-scan & .796 & \\
\hline It is fun to scan the items yourself & .879 & \\
\hline Perceived control & Mean 5.680 & $.86(.790)$ \\
\hline The self-scan gives me control & .897 & \\
\hline The self-scan lets the customer be in charge & .880 & \\
\hline
\end{tabular}

and fun/enjoyment were viewed as less important factors. The coefficient of determination $\left(R^{2}=0.518\right)$ tends to be influenced by the sample size and is considered to be an optimistic measure of quality (Hair et al. 2009). Alternatively it is possible to use the adjusted $R^{2}$ (adjusted $R^{2}=0.510$ ). $51 \%$ of the variability of the perceived quality of self-checkout is explained by its attributes. The analysis of the simple correlation coefficient $(R=0.72)$ suggests that there is a high positive correlation $(R>0.6)$ between the variables (Table 4$)$.

Hypothesis 2 was also supported (Table 5). By analyzing the simple correlation coefficient $(R=0.698)$, we verified that there is a good positive correlation $(R>0.6)$ between the variables. The adjusted coefficient of determination (adjusted $R^{2}=0.486$ ) suggests that $48.6 \%$ of the variability of overall satisfaction is explained by perceived quality with self-checkout.

Similar to Hypothesis 1 and 2, Hypothesis 3 was also supported. By analyzing the simple correlation coefficient $(R=0.622)$ we verified that there is a good positive correlation $(R>0.6)$ between the variables. The adjusted coefficient of determination (adjusted $R^{2}=0.385$ ) suggests that $38.5 \%$ of the variability of the intention to repatronize the store is (in part) explained by overall satisfaction with the service experience (Table 6).

Multivariate analysis of variance (MANOVA) ascertained the impact of usage frequency and demographic variables on self-checkout attribute evaluation (Table 7). Firstly the multivariate interaction effect was examined and two variables (age and frequency of use) proved to be significant discriminators (Roy's largest root $<.002$ and $<.000$, respectively) while gender and education had no significant impact on self-checkout attribute evaluation. Thus, Hypothesis 4 was supported, while Hypothesis 5 was only partially supported. In order to determine 
Table 4 H1 testing results: Regression analysis between self-scan attributes and perceived quality

\begin{tabular}{lccccr}
\hline$R$ & $R^{2}$ & \multicolumn{2}{c}{ Adjusted $R^{2}$} & \multicolumn{2}{c}{ Durbin-Watson } \\
\hline 0.720 & 0.518 & \multicolumn{2}{c}{0.510} & 1.994 & \\
\hline ANOVA & Sum of squares & DF & Mean square & F & Sig. \\
\hline Regression & 271.184 & 5 & 54.237 & 60.936 & 0.000 \\
Residual & 251.889 & 283 & 0.890 & & \\
Total & 523.073 & 288 & & & \\
\hline Coefficients & $\mathrm{B}$ & Std. error & Beta & $\mathrm{T}$ & Sig. \\
\hline Constant & 5.322 & 0.055 & & 95.895 & 0.000 \\
Speed & 0.484 & $0 . .056$ & 0.173 & 4.203 & 0.000 \\
Ease-of-use & 0.487 & 0.056 & 0.361 & 8.753 & 0.000 \\
Reliability & 0.586 & 0.056 & 0.435 & 10.537 & 0.000 \\
Entertainment & $0 . .234$ & 0.056 & 0.173 & 4.203 & 0.000 \\
Perceived Control & 0.270 & 0.056 & 0.201 & 4.865 & 0.000 \\
\hline
\end{tabular}

Table 5 H2 testing results: Regression analysis between perceived quality and satisfaction

\begin{tabular}{|c|c|c|c|c|c|}
\hline \multirow{3}{*}{$\begin{array}{l}R \\
0.698 \\
\text { ANOVA }\end{array}$} & \multirow{3}{*}{$\begin{array}{c}R^{2} \\
0.488 \\
\text { Sum of squares }\end{array}$} & \multirow{2}{*}{\multicolumn{2}{|c|}{$\begin{array}{l}\text { Adjusted } R^{2} \\
0.486\end{array}$}} & \multicolumn{2}{|c|}{$\overline{\text { Durbin-Watson }}$} \\
\hline & & & & & \\
\hline & & DF & Mean square & $\mathrm{F}$ & Sig. \\
\hline Regression & 285.894 & 1 & 285.894 & 278.156 & 0.00 \\
\hline Residual & 300.123 & 292 & 1.028 & & \\
\hline Total & 586.017 & 293 & & & \\
\hline Coefficients & B & Std. error & Beta & $\mathrm{T}$ & Sig. \\
\hline Constant & 1.687 & 0.242 & & 6.956 & 0.00 \\
\hline Quality & 0.737 & 0.044 & 0.698 & 16.678 & 0.000 \\
\hline
\end{tabular}

the nature and magnitude of age and frequency impact, a series of univariate analyses was conducted. The result showed that age had no effect on speed, ease-ofuse, fun/entertainment, and reliability $(p>0.01)$, but had a significant effect on perceived control $(p=0.004)$. An analysis of perceived control showed that the difference was most pronounced among younger customers (less than 30 years old) having a higher sense of control $(\mathrm{M}$ younger $=0.302)$, when compared with middle-aged (between 30 and 50 years old) and older (more than 50 years old) customers $(\mathrm{M}$ middle $=-0.176$; $\mathrm{M}$ older $=-0.006$ ).

The analysis also showed usage frequency to be an effective discriminator. Frequency of use accounted for differences related with fun/entertainment and easeof-use. Consumers who rarely or occasionally use self-checkout are less likely to find the technology fun/entertaining than those who always use it $(\mathrm{M}$ always $=0.297 ; \mathrm{M}$ 
Table 6 H3 testing results: Regression analysis between satisfaction and repatronage intention

\begin{tabular}{|c|c|c|c|c|c|}
\hline \multirow{3}{*}{$\begin{array}{l}R \\
0.622 \\
\text { ANOVA }\end{array}$} & \multirow{3}{*}{$\begin{array}{c}R^{2} \\
0.387 \\
\text { Sum of squares }\end{array}$} & \multirow{2}{*}{\multicolumn{2}{|c|}{$\begin{array}{l}\text { Adjusted } R^{2} \\
0.385\end{array}$}} & \multicolumn{2}{|c|}{ Durbin-Watson } \\
\hline & & & & & \\
\hline & & $\mathrm{DF}$ & Mean square & $\mathrm{F}$ & Sig. \\
\hline Regression & 274.932 & 1 & 274.932 & 184.102 & 0.000 \\
\hline Residual & 436.065 & 292 & 1.493 & & \\
\hline Total & 710.997 & 293 & & & \\
\hline Coefficients & B & Std. error & Beta & $\mathrm{T}$ & Sig. \\
\hline Constant & 2.162 & 0.292 & & 7.404 & 0.000 \\
\hline Satisfaction & 0.685 & 0.050 & 0.622 & 13.568 & 0.000 \\
\hline
\end{tabular}

Table 7 H4 and H5 testing results: Multivariate analysis of variance

\begin{tabular}{lllll}
\hline & Age & Gender & Education & Usage frequency \\
\hline Roy's largest root & $0.002^{*}$ & 0.348 & 0.300 & $0.000^{*}$ \\
Speed & 0.055 & 0.633 & 0.306 & 0.093 \\
Ease-of-use & 0.534 & 0.180 & 0.785 & $0.008^{*}$ \\
Reliability & 0.029 & 0.916 & 0.790 & 0.567 \\
Fun/entertainment & 0.139 & 0.400 & 0.045 & $0.000^{*}$ \\
Perceived control & $0.004^{*}$ & 0.049 & 0.285 & 0.170 \\
\hline
\end{tabular}

* Statistically significant at $p<0.01$

rare $=-0.190 ; \mathrm{M}$ occasion $=-0.260)$. Pairwise differences were also found between frequent $(\mathrm{M}$ frequent $=0.021)$ and rare users. An analysis of perceived ease-of-use showed that consumers who use self-checkout all the time are more likely to evaluate it significantly higher $(\mathrm{M}$ always $=1.86)$ than consumers who rarely use it $(\mathrm{M}$ rare $=-3.91)$. Usage frequency didn't have any effect on the evaluation consumers made of speed $(p=0.093)$, reliability $(p=0.567)$, and sense of control $(p=0.170)$.

\section{Conclusion}

The study of self-service technology (SST) has gained widespread interest in recent years. In particular, the proliferation of new SSTs in the retail settings, namely selfcheckouts, suggests a need to better understand factors that may affect consumers' evaluation of this technology, which requires customers to play an active role. Despite the fact that a significant amount of research has been done in recent years, previous studies focused heavily on SST adoption, with on-site technologies receiving less attention than the off-site options. The purpose of this paper is to extend recent research that has investigated the factors driving consumer use of self- 
checkout technology. Specifically, this study assesses which SST attributes influence customer evaluations of self-checkout quality in a retail transaction, and if this impacts their overall satisfaction with the service experience and retail patronage, while also considering the effects of use frequency and customer characteristics.

The empirical results support the conceptual framework proposed in this study and the main findings of previous literature (e.g., Dabholkar et al. 2003; Beatson et al. 2006). There is evidence that self-checkout attributes positively impact user perceptions of service quality. Speed of using the service and perceived ease-of-use emerged as important determinants of customers' evaluation of self-checkout quality. Interestingly, reliability was considered the most important determinant of self-service quality. According to Meuter et al. (2000), this could be explained by the novelty of the technology, which makes performing ("doing its job") accurately a source of satisfaction. Perceived control and fun/enjoyment were viewed as less important factors, in spite of the results obtained by e.g., Marzocchi and Zammit (2006). However, the importance given to some attributes was different according to the customer's age and frequency of use. Namely, younger customers are more likely to perceive a higher sense of control over the technology, while more regular users find it more fun/entertaining and easier to use. Moreover, perceptions of service quality determine overall satisfaction which, in turn, has a positive impact on the intention to repatronize the store. Our study contributes to bridging the literature gap on SST, a relatively new self-checkout technology, focusing on a real-life retail scenario and analyzing actual usage and outcomes. We also look at additional factors by considering the role of usage frequency and customer characteristics.

Results offer strategic implications not only for retailers but also for other service industries where technology-based self-service options may be considered. Since scant research exists on customer expectations of SST service quality in general (Lin and Hsieh 2011) and self-checkout in particular (Lee et al. 2009), a main research issue in the study was to determine consumer criteria for assessing SST service quality while using self-checkouts in supermarkets. Following Dabholkar's (1996) attribute-based model, our findings suggest that customers base their perception of self-checkout quality on five primary dimensions: speed, ease-of-use, control, reliability, and enjoyment. These results underscore the need for service providers to place extra emphasis on these dimensions in order to ensure that their technology-based self-service option offers the specific attributes consumers actually value. By understanding what factors affect a customer's choice, better strategies can be developed to manage and coordinate multiple service delivery options. The study shows that each dimension contributes differentially to customers' overall service quality perceptions. Practitioners can use these results to conduct a comprehensive assessment of SST service quality in order to better understand customer perceptions, pinpoint the specific areas where gaps exist and concentrate resources on improving particular aspects of service quality. Periodic quality surveys across dimensions can be set, allowing managers to e.g., identify problem areas with their SST or to measure effects of modifications.

The attributes of SST that service managers should focus on, include: how much time saving and speed are provided by SST systems; the ease-of-use of SSTs; and 
whether the SST is perceived as reliable and accurate. Thus, providers should not only build awareness of these attributes through e.g., promotional campaigns, but also clearly show customers how SSTs provide additional benefits in the service process. This may also have consequences in terms of the importance given by providers to e.g., service promptness and convenience, customer education, and service recovery. Firms offering SST can design clear usage guidelines in order to increase perceived speed; interfaces that are simple and user-friendly to increase the ease-of-use; and/or more reliable operating systems to lower the frequency of service failure and to increase accuracy.

Another managerial contribution of this study lies in the extension of previous research related to SST adoption. Previous studies focused heavily on reasons for adoption and intention to use SST, while limited research exists on post-usage behavior, namely its impact on satisfaction and retention. An important finding of our research was that service quality delivered by self-checkouts is positively related to customer overall satisfaction with the retail service and retail patronage intentions. These results suggest that consumers view the service delivered by selfcheckouts as part of the total customer service experience with a retail store. Thus, consumers who perceive high service quality when using self-checkouts are likely to consider the retailer to be responsible for providing a superior customer service, which ultimately leads to retail patronage intention. This is good news for supermarket chains as well as for other retailers considering this option. Given the positive consequences that perceptions of self-checkout quality have on the overall opinion of the supermarket and on the intention to repatronize the store, its presence may lend a competitive advantage and offer the service provider the possibility of expanding its customer base. However, retailers should not be satisfied with the mere introduction of SST as an indication that they are providing high-quality service. Simply incorporating technology-based services may not be enough. Rather, retailers should endeavor to increase service quality delivered through selfcheckout by designing and promoting attributes of self-service checkout which will lead to better evaluations of service quality, and thus to higher overall satisfaction and intention to return to the store. Namely, while implementing SST, providers must be aware that the five dimensions covered in this study can serve as a guide to develop superior service quality that enhances customers' behavioral intentions, which may eventually 'tie' consumers to the firm.

Another research issue was to explore the possible influence of usage frequency and customer traits. Understanding customer differences in the evaluation of selfcheckout quality will enable retailers to implement well-suited customer service strategies to certain groups. Considering the impact of age on perceived control, managers should pay special attention to the support given to middle-aged and older customers, who may otherwise feel helpless and avoid the use of self-service checkout due to a perceived loss of control over the situation and social risk. Unsurprisingly, customers who regularly use SST find them easier to use than those who rarely or occasionally use them. Since ease-of-use was found to be one of the main determinants of self-checkout quality, encouraging repeated usage may translate into more satisfied and loyal customers. Interestingly, regular use and interaction with the technology also leads to a higher sense of fun and entertainment 
beyond the transaction and utilitarian value of self-checkout, i.e., SST may be engaging (Vivek et al. 2012). Although it is beyond the scope of this paper to fully review the growing body of literature on customer engagement, an understanding of the enjoyment factor of using SSTs can assist service managers is assessing users (i.e., regular users) demands. While organizations increasingly invest in fun retail experiences, service managers may need to look beyond SST usability and usefulness-enhancing features and also consider it as a hedonic experience, since this may act as an antecedent of a dynamic engagement process (Brodie et al. 2011).

Having discussed managerial implications along with the presentation of our findings, it is important to acknowledge some possible limitations. In particular, future research might expand beyond the single context of the current research to multiple contexts. The validation of the results at e.g., a retailer could further contribute to the robustness of the study. Moreover, although we focus on outcomes such as satisfaction and repatronage, future studies could focus on other behaviors such as word-of-mouth. Also, the conceptual model presented should be a starting point to determine whether other constructs should be included to provide a more complete understanding of SST evaluation. Although the attributes proposed in the model explain approximately half of the variations in SST assessments, it is important to know what determinants account for the other half. Recent research has suggested convenience (e.g., Collier and Kimes 2013), technology newness (e.g., Weijters et al. 2007), trust in the organization (e.g., Collier and Sherrell 2010), and design and interface features (e.g., Lee et al. 2013) as other possible relevant antecedents. Moreover, other situational and individual characteristics (e.g., number of items being purchased, the need for personal interaction, technological anxiety, and self-efficacy) could also be considered relevant factors for understanding self-checkout evaluation. Future studies could further elaborate on the potential drivers and inhibitors of technology readiness (Parasuraman 2000). Another interesting avenue for further research would be to also focus on non-users (e.g., Weijters et al. 2007; Collier and Kimes 2013) and to understand differences between customers in terms of SST evaluation in retail. Future research could further develop a longitudinal study (e.g., Wang et al. 2013) in which the effect of the outcomes of using SST on one occasion has an impact on the attitudes toward the SST on the next occasion. Also, our study focuses solely on self-checkout. However, today in a retailing context, SST is just one of multiple channels available to customers. Customers are not only faced with the choice of using either personal service or an SST, but also have a variety of SST modes to choose from. It is important to understand not only why customers adopt SST, but also why they prefer one SST over another and what induces the use of a specific service channel (Liljander et al. 2006). Thus, future studies should examine a multi-channel context instead of SST in isolation in order to investigate other relevant factors that may influence customer choice with regard to SST.

\section{References}

Ajzen I, Fishbein M (1980) Understanding attitudes and predicting social behavior. Prentice-Hall, Englewood Cliffs 
Anitsal I, Schumann D (2007) Towards a conceptualization of customer productivity: the customer's perspective on transforming customer labour into customer outcomes using technology-based selfservice options. J Mark Theory Prac 15(4):349-363. doi:10.2753/MTP1069-6679150405

Anselmsson J (2001) Customer-perceived quality and technology-based self-service. Business Press, Lund

Baron S, Patterson A, Harris K (2006) Beyond technology acceptance: understanding consumer practice. Int J Serv Ind Manag 17(2):111-135. doi:10.1108/09564230610656962

Bateson J (1985) Self-service consumer: an exploratory study. J Ret 61(3):49-76

Bateson J, Hui M (1987) Perceived control as a crucial perceptual dimension of the service experience: an experimental study. In: Suprenant C (ed) Add value to your service: the key to success. Ill: American Marketing Association, Chicago, pp 187-192

Beatson A, Coote L, Rudd J (2006) Determining consumer satisfaction and commitment through selfservice technology and personal service usage. J Mark Manag 22:853-882. doi:10.1362/ 026725706778612121

Beatson A, Lee N, Coote L (2007) Self-service technology and the service encounter. T Serv Ind J 27(1):75-89. doi:10.1080/02642060601038700

Bitner M, Ostrom A, Meuter M (2002) Implementing successful self-service technologies. Acad Manag Exe 15(4):96-108. doi:10.5465/AME.2002.8951333

Brodie R, Hollebeek L, Juric B, Ilic A (2011) Customer engagement: conceptual domain, fundamental propositions and implications for research. J Serv Res 14(3):252-271. doi:10.1177/10946705 11411703

Buell R, Campbell D, Frei F (2010) Are self-service customers satisfied or stuck. Prod Op Manag 19(6):679-697. doi:10.1111/j.1937-5956.2010.01151.x

Childers T, Carr C, Peck J, Carson S (2001) Hedonic and utilitarian motivations for online retail shopping behavior. J Ret 77:511-535. doi:10.1016/S0022-4359(01)00056-2

Chiu Y, Fang S, Tseng C (2010) Early versus potential adopters: exploring the antecedents of use intention in the context of retail service innovations. Int J Ret Dist Manag 38(6):443-459. doi:10. $1108 / 09590551011045357$

Collier J, Kimes S (2013) Only if it is convenient: understanding how convenience influences self-service technology evaluation. J Serv Res 16(1):39-51. doi:10.1177/1094670512458454

Collier J, Sherrell D (2010) Examining the influence of control and convenience in a self-service setting. J Aca Mark Sci 38:490-509. doi:10.1007/s11747-009-0179-4

Cunningham L, Young C, Gerlach J (2008) Consumer views of self-service technologies. T Serv Ind J 28(6):719-732. doi:10.1080/02642060801988522

Curran J, Meuter M (2005) Self-service technology adoption: comparing three technologies. J Serv Mark 19(2):103-113. doi:10.1108/08876040510591411

Curran J, Meuter M (2007) Encouraging existing customers to use self-service technologies: put a little fun in their lives. J Mark Theory Prac 15(4):283-298. doi:10.2753/MTP1069-6679150401

Curran J, Meuter M, Surprenant C (2003) Intentions to use self-service technologies: a confluence of multiple attitude. J Serv Res 5(3):209-224. doi:10.1177/1094670502238916

Dabholkar P (1994) Incorporating choice into an attitudinal framework: analyzing models of mental comparison processes. J Con Res 21(1):100-109. doi:10.1086/209385

Dabholkar P (1996) Consumer evaluations of new technology-based self-service options: an investigation of alternative models of service quality. Int J Res Mark 13(1):29-51. doi:10.1016/01678116(95)00027-5

Dabholkar P, Bagozzi R (2002) An attitudinal model of technology-based self-service: moderating effects of consumer traits and situational factors. J Aca Mark Sci 30(3):184-201. doi:10.1177/ 0092070302303001

Dabholkar P, Spaid B (2012) Service failure and recovery in using technology-based self-service: effects on user attributions and satisfaction. Serv Ind J 32(9):1415-1432. doi:10.1080/02642069.2011. 600518

Dabholkar P, Bobbitt M, Lee E (2003) Understanding consumer motivation and behavior related to selfscanning in retailing - Implications for strategy and research on technology-based self-service. Int $\mathrm{J}$ Serv Ind Manag 14(1):59-95. doi:10.1108/09564230310465994

Davis F (1989) Perceived usefulness, perceived ease of use and user acceptance information technology. MIS Quart 13(3):319-340. doi:10.1145/358080.358095 
Davis S, Wiedenbeck S (2001) The mediating effects of intrinsic motivation, ease of use and usefulness perceptions on performance in first-time and subsequent computer users. Interact Comput 13(5):549-580. doi:10.1016/S0953-5438(01)00034-0

Dean D (2008) Shopper age and the use of self-service technologies. Manag Serv Qua 18(3):225-238. doi:10.1108/0960452081087185610.1177

DeJong A, de Ruyter K, Lemmink J (2003) The adoption of information technology by self-managing service teams. J Serv Res 6(2):162-179

Ding X, Verma R, Iqbal Z (2007) Self-service technology and online financial service choice. Int J Serv Ind Manag 18(3):246-268. doi:10.1108/09564230710751479

Ding X, Hu P, Sheng O (2011) e-SELFQUAL: a scale for measuring online self-service quality. J Bus Res 64(5):508-515. doi:10.1016/j.jbusres.2010.04.007

Elliott K, Hall M (2005) Assessing consumers' propensity to embrace self-service technologies: are there gender differences. Mark Manag J 15(2):98-107

Elliott K, Meng G, Hall M (2012) The influence of technology readiness on the evaluation of self-service technology attributes and resulting attitude toward technology usage. Serv Mark Qual 33(4):311-329. doi:10.1080/15332969.2012.715049

Elliott K, Hall M, Meng G (2013) Consumers' intention to use self-scanning technology: the role of technology readiness and perceptions toward self-service technology. Ac Mark Stud J 17(1):311-329

Evans K, Brown S (1988) Strategic options for service delivery systems. In: Ingene CA, Frazier GL (eds) Proceedings of the AMA Summer Educators' Conference. American Marketing Association, Chicago, pp 207-212

Fornell C, Larcker D (1981) Evaluating structural equation models with unobservable variables and measurement error. J Mark Res 18(1):39-50. doi:10.2307/3151312

Hair J, Black W, Babin B, Anderson R, Tatham R (2009) Multivariate analysis, 7th edn. Prentice Hall, Englewood Cliffs

Hilton, T, Hughes, T (2013) Co-production and co-creation using self-service technology: The application of service dominant logic. J Mark Manag 29:861-881. doi:10.1080/0267257X.2012.729071

Hilton T, Hughes T, Little E, Marandi E (2013) Adopting self-service technology to do more with less. J Serv Mark 27(1):3-12. doi:10.1108/08876041311296338

Hirschman E, Holbrook M (1982) Hedonic consumption: emerging concepts, methods and proposition. J Mark 46:92-101. doi:10.2307/1251707

Howard M, Worboys C (2003) Self-service-a contradiction in terms or customer-led choice. J Cons Behav 2(4):382-392. doi:10.1002/cb.115

Hsieh A, Yen C, Chin K (2004) Participative customers as partial employees and service provider workload. Int J Serv Ind Manag 15(2):187-199. doi:10.1108/09564230410532501

Im S, Bayus B, Mason C (2003) An empirical study of innate consumer innovativeness, personal characteristics, and new-product adoption behavior. J Aca Mark Sci 31(1):61-73. doi:10.1177/ 0092070302238602

Kallweit K, Spreer P, Toporowski W (2014) Why do customers use self-service information technologies in retail? The mediating effect of perceived service quality. J Retail Consum Serv 21(3):268-276. doi:10.1016/j.jretconser.2014.02.002

Kelly P, Lawlor J, Mulvey M (2010) Review of key factors affecting consumers' adoption and usage of self-service technologies in tourism, THRIC Conference, Shannon, 15-16 June, 2010

Kuo Y, Wu C, Deng W (2009) The relationships among service quality, perceived value, customer satisfaction and post-purchase intention in mobile value-added services. Comput Hum Behav 25(4):887-896. doi:10.1016/j.chb.2009.03.003

Langeard E, Bateson J, Lovelock C, Eiglier P (1981) Services marketing: new insights from consumers and managers. Marketing Science Institute, Cambridge

Lee J, Allaway A (2002) Effects of personal control on adoption of self-service technology innovations. J Serv Mark 16(6):553-572. doi:10.1108/08876040210443418

Lee H, Yang K (2013) Interpersonal service quality, self-service technology (SST), service quality and retail patronage. J Retail Consum Serv 20(1):51-57. doi:10.1016/j.jretconser.2012.10.005

Lee H, Fairhurst A, Lee M (2009) The importance of self-service kiosks in developing consumers' retail patronage intentions. Manag Serv Qual 19(6):687-701. doi:10.1108/09604520911005071

Lee H, Cho H, Xu W, Fairhurst A (2010) The influence of consumer traits and demographics on intention to use retail self-service checkouts. Mark Int Plan 28(1):46-58. doi:10.1108/02634501011014606 
Lee H, Fairhurst A, Cho H (2013) Gender differences in consumer evaluations of service quality: selfservice kiosks in retail. T Serv Ind J 33(2):248-265. doi:10.1080/02642069.2011.614346

Liljander V, Gillberg F, Gummerus J, Van Riel A (2006) Technology readiness and the evaluation and adoption of self-service technologies. J Retail Consum Serv 13(3):177-191. doi:10.1016/j. jretconser.2005.08.004

Lim H, Dubinsky A (2004) Consumers' perceptions of e-shopping characteristics: an expectancy-value approach. J Serv Mark 18(7):500-513. doi:10.1108/08876040410561839

Lin C, Hsieh P (2006) The role of technology readiness in customers' perception and adoption of selfservice technologies. Int J Serv Ind Manag 17(5):497-517. doi:10.1108/09564230610689795

Lin C, Hsieh P (2007) The influence of technology readiness on satisfaction and behavioral intentions toward self-service technologies. Comput Hum Behav 23(3):1597-1615. doi:10.1016/j.chb.2005.07. 006

Lin C, Hsieh P (2011) Assessing the self-service technologies encounters: development and validation of SSTQUAL scale. J Ret 87(2):194-206. doi:10.1016/j.retai.2011.02.006

Lusch R, Vargo S (2006) Service-dominant logic: reactions, reflections and refinements. Mark 6(3):281-288. doi:10.1177/1470593106066781

Marzocchi G, Zammit A (2006) Self-scanning technologies in retail: determinants of adoption. T Serv Ind J 26(6):651-669. doi:10.1080/02642060600850790

Meuter M, Ostrom A, Roundtree R, Bitner M (2000) Self-service technologies: understanding consumer satisfaction with technology-based service encounters. J Mark 64(3):50-64. doi:10.1016/S01482963(01)00276-4

Meuter M, Ostrom A, Bitner M, Roundtree R (2003) The influence of technology anxiety on consumer use and experiences with self-service technologies. J Bus Res 56(11):899-906. doi:10.1016/S01482963(01)00276-4

Meuter M, Bitner M, Ostrom A, Brown S (2005) Choosing among alternative service delivery modes: an investigation of customer trial of self-service technologies. J Mark 69(2):61-83. doi:10.1509/jmkg. 69.2.61.60759

Nilsson D (2007) A cross-cultural comparison of self-service technology use. Eur J Mark 41(3/ 4):367-381. doi:10.1108/03090560710728381

Nunnally J (1978) Psychometric theory, 2nd edn. McGraw-Hill, New York

Oghazi P, Mostaghel R, Hultman M, Parida V (2012) Antecedents of technology-based self-service acceptance: a proposed model. Serv Mark Qual 33:195-210. doi:10.1080/15332969.2012.689937

Oliver R (1997) Satisfaction: a behavioral perspective on the consumer. McGraw-Hill

Orel F, Kara A (2014) Supermarket self-checkout service quality, customer satisfaction, and loyalty: empirical evidence from an emerging market. J Retail Consum Serv 21(4):118-129. doi:10.1016/ jretconser.2013.07002

Pantano E, Viassone M (2014) Demand pull and technology pull perspective in technology-based innovations for the points-of-sale: the retailers evaluation. J Retail Consum Serv 21(1):43-47. doi:10.1016/j.jretconser2013.06.007

Parasuraman A (2000) Technology readiness index (TRI): a multiple-item scale to measure readiness to embrace new technologies. J Serv Res 2(4):307-320. doi:10.1177/109467050024001

Parasuraman A, Zeithaml V, Berry L (1988) SERVQUAL: a multiple-item scale for measuring consumers perceptions of service quality. J Ret 64(1):12-40

Rayport J, Jaworski B (2004) Best face forward. Harv Bus Rev 82(12):47-58. doi:10.1225/R0412B

Reinders M, Dabholkar P, Frambach R (2008) Consequences of forcing consumers to use technologybased self-service. J Serv Res 11(2):107-123. doi:10.1177/1094670508324297

Renko S, Druzijanic M (2014) Perceived usefulness of innovative technology in retailing: consumers' and retailers' point of view. J Retail Consum Serv 21(1):836-843. doi:10.1016/j.jretconser.2014.02.015

Rodie A, Kleine S (2000) Customer participation in services production and delivery. In: Swartz T, Iacobucci D (eds) Handbook of services marketing and management. Sage, Thousand Oaks, pp 111-125

Simon F, Usunier J (2007) Cognitive, demographic, and situational determinants of service customer preference for personnel-in-contact over self-service technology. Int J Res Mark 24(2):163-173. doi:10.1016/j.ijresmar.2006.11.004

Timmor Y, Rymon T (2008) Don't imitate, innovate: the case of a hybrid education format in a management course. Int J Inf Op Manag Edu 2(4):341-357. doi:10.1504/IJIOME.2008.023438

Van Riel A, Semeijn J, Hammedi W, Henseler J (2011) Technology-based service proposal screening and decision-making effectiveness. Manag Decis 49(5):762-783. doi:10.1108/00251741111130841 
Vargo S, Lusch R (2008) Service-dominant logic: continuing the evolution. J Aca Mark Sci 36(1):1-10. doi:10.1007/s11747-007-0069-6

Vivek S, Beatty S, Morgan R (2012) Customer engagement: exploring customer relationships beyond purchase. J Mark Theory Prac 20(2):127-145. doi:10.2753/MTP1069-6679200201

Walker R, Johnson L (2006) Why consumers use and do not use technology enabled services. J Serv Mark 20(2):125-135. doi:10.1108/08876040610657057

Walker R, Craig-Lees M, Hecker R, Francis H (2002) Technology-enabled service delivery: an investigation of reasons affecting customer adoption and rejection. Int $\mathrm{J}$ Serv Ind Manag 13(1):91-106. doi:10.1108/09564231211208970

Wang M Chih-Hung (2012) Determinants and consequences of consumer satisfaction with self-service technology in a retail setting. Manag Serv Qual 22(2):128-144. doi:10.1108/09604521211218945

Wang C, Harris J, Patterson P (2012) Customer choice of self-service technology: the roles of situational influences and past experience. J Serv Manag 23(1):54-78. doi:10.1108/09564231211208970

Wang C, Harris J, Patterson P (2013) The roles of habit, self-efficacy, and satisfaction in driving continued use of self-service technologies a longitudinal study. J Serv Res 16(3):400-414. doi:10. $1177 / 1094670512473200$

Weijters B, Rangarajan D, Falk T, Schillewaert N (2007) Determinants and outcomes of customers' use of self-service technology in a retail setting. J Serv Res 10(1):3-21. doi:10.1177/1094670507302990

Yang J, Klassen K (2008) How financial markets reflect the benefits of self-service technologies. J Ent Inf Manag 21(5):448-467. doi:10.1108/17410390810904238

Zhao X, Mattila A, Tao L (2008) The role of post-training self-efficacy in customers' use of self service technologies. Int J Serv Ind 19(4):492-505. doi:10.1108/09564230810891923

Zhu Z, Nakata C, Sivakumar K (2007) Self-service technology effectiveness: the role of design features and individual traits. J Aca Mark Sci 35:492-506. doi:10.1007/s11747-007-0019-3

Zhu Z, Nakata C, Sivakumar K, Grewal D (2013) Fix it or leave it: customer recovery from self-service technology failure. J Retail 89(1):15-29. doi:10.1016/j.jretai.2012.10.004 